\title{
4 無機ポーラログラフ分析
}

神原富民・林謙次 郎*

\section{$4 \cdot 1$ 著書と総 説}

今期にあらわれたテキストブックとしては，日本語1 とドイツ語2の力作があり，いずれも新しい方法論の解 説に努力が払われている. また, Heyrovsky のノーベ ル賞受賞を記念した総説集引が発行され，この方面の最 近の進歩を知るのに都合がよい。日本では, 交流ポーラ ログラフィーをテーマとした特集号4が発行されたが， その水準沙交の本より高いと言えよう.

定期的総説としては, 分析化学誌およびAnal. Chem. 飞掲載されるものについては，今さら述べる必要はなか ろう.ほかに,「電気化学の進歩」5)には, ポーラログラ フィーのみならず, 理論電気化学や測定法など, 関連分 野の進歩がまとめられている。

交献集は, Heyrovsky によるものと Semerano に よるものが有名である・㐫たメーカーから出されている ものとしては，「躍隻する機器」(柳本製作所）がある. 日本ポーラログラフ学会編の「ポーラログラフィー・文 献・データ・カード」は, 第一期として400 枚のパン チ・カードを発行した(技研社). 国別, 年代別に交献数 の変動を調べた報告がある6).

総説としては，全般的なもの?，教育面から見たも の8), 測定法・装置9 11) 関するもの, ESR ${ }^{12) 13)}$ との 関連を論じたもの，直流ポーラログラフィーについての 力作 ${ }^{14) 15)}$, 非可逆波 ${ }^{16)}$, 工業プロセスにおける自動化へ の応用17を述べたものがある。

\section{$4 \cdot 2$ 方 法 論}

Surface Polarography ${ }^{18)}$, Anodic Stripping ${ }^{19) 20}$, 流動効果の検討21), 何電電流補正法22), 粘度の影響23224),

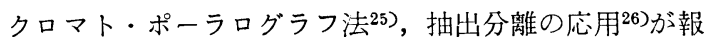
告された。電解電流におよぼす交流電場の効果 ${ }^{27}$ 28), 電 量測定における滴下水銀電極の利用 ${ }^{29}$, , Potential Step 法 ${ }^{30)}$, 放射能ポーラログラフ法 ${ }^{31)}$, 方形波電流規制法 ${ }^{32}$ が研究された. 方形波およびパルスポーラログラフ法に

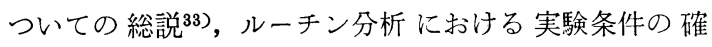
立 ${ }^{34)}$, 実験技術35)が論ぜられた。

\footnotetext{
* 北海道大学理学部化学教室 (札幌市北 10 条西 8 丁目)
}

常法のポーラログラフ法では, 標準添加法における誤 差 ${ }^{36)}$, 対極の分極による異状波 ${ }^{37)}$, ヒドラジン電極によ る除酸素法 ${ }^{38)}$, 電気的マスキング39)が述べられた。

交流ポーラログラフィー4）については，いろいろな立 場からの総合的記述40) 44) があり, 速度定数 ${ }^{45)}$, 原理に ついての論争46)47), 新しい型のピーク48), 二重層の研 究49), 陰極線オッシログラフの利用 ${ }^{50)}$, 大きな電圧振幅の 効果 ${ }^{51}$, 電解整流 ${ }^{52}$, 容量性電流補(賞回路 ${ }^{53)}$, 迅速滴下電 極の利用 ${ }^{54)}$, 基礎理論の検討 55) 58)があり, Cambridge Univector 装置の解釈 ${ }^{59)}$, Booman $の$ 回路60), 第二高調 波 ${ }^{61)}$, 八ロゲン-ハロゲンイオン系の可逆度 ${ }^{62)}$, 符号の とり方 ${ }^{63)}$, 増感装置 ${ }^{64)}$, セルのインピーダンスと分極の

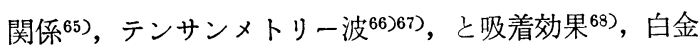
極の表面状態(9), 方形波法に抢ける支持塩濃度の効果 ${ }^{70)}$ が研究された.

クロノポテンシォメトリーについては, 不均一化反応 による復極剂の生成 ${ }^{71)}$, 滴下水銀電極の利用 ${ }^{72}$, 全反応 機構の決定法 ${ }^{73)}$, 電流を step-function の形で変える

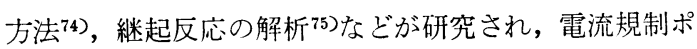
一ラログラフィー76) 78) も引き続き検討されている.

オッシロポーラログラフ法については, 単掃引法79), $\mathrm{H}-\mathrm{F}$ 型 ${ }^{80)}$ についての総報, ポテンシャル・スイープを 掛ける方法を逆転させる方法 ${ }^{81)}$, 振動電極 ${ }^{82}$, つり下げ電 極83)の利用, 微量生物学への応用 ${ }^{84)}$, anodic stripping の侻用 ${ }^{85)}$, 方形波ポーラログラムの観測86), $d i / d t$ の理 論87)，2 個のジェット極を用いる示差法 ${ }^{88)}, \mathrm{U}(\mathrm{HI})$ 波の 速度論 ${ }^{89)}, \mathrm{Tl}(\mathrm{I})-\mathrm{Tl}(\mathrm{Hg})$ 系の $\mathrm{k}_{2}=1.25$ の評価90), 複式セル示差法 ${ }^{11)}, \mathrm{H}-\mathrm{F}$ 型による kinetic parameter

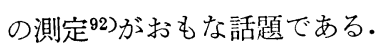

Coulostatic Method と呼ばれる新しい方法93394)で は, 電極に荷電のパルスを与えて, 電位・時間曲線が記 録され， $10^{-5} \sim 10^{-7} M$ の微量定量が可能である.

非水溶媒ポーラログラフィーについては, 総説 ${ }^{95) ~ 97) ~}$ のほかに, Kalousek 回路の利用98), ジメチルスルホキ シド98j99), 液体アンモニア100), 特に高圧用 $\left(25^{\circ}, 10\right.$ 気

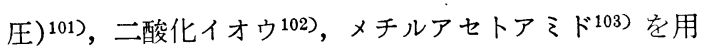
いる方法, $i R$ 補償装置 ${ }^{104)}$ が報告された.

溶融塩ポーラログラフィーについては, 総説105) のほ 


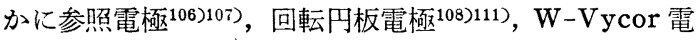
極 ${ }^{109)}, \mathrm{H}-\mathrm{F}$ 型オッシログラフ法110), galvanostatic な 方法112)113)が研究され, 塩化物浴107)109)111)114) 119), 硝酸

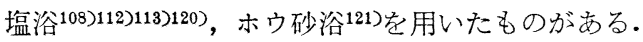

\section{$4 \cdot 3$ 装置}

セルについては, 総説 ${ }^{122)}$, 万能型 ${ }^{123)}$, 温度可変型124), 流液用 ${ }^{125)}$, 燃焼用ミク口型126) の報告があり, 水銀蒸留

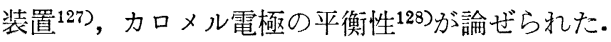

指示電極については，多くの報告がある. 滴下水銀電 極 (DME) については, 諸変形の総括 ${ }^{129}, m, t, w$ の自 動測定 ${ }^{130)}$, 高感度ポーラログラフにおける特性 ${ }^{131)}$, 迅

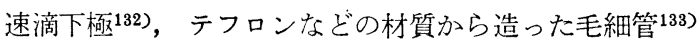
134), 酸素定量用の大口径毛細管 ${ }^{135) 136)}$, 高速シネマによ る研究 ${ }^{137)}$, 回転 DME の総説 ${ }^{138)}$, 滴下アマルガム電 極 ${ }^{139}$ ), 振動 $\mathrm{DME}{ }^{140)}$ (オッシロポーラログラフ用) が 述ベられた。

つり下げ雪樰については総説141) 151), そのほかの報告

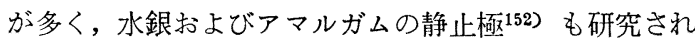
ている.

固体電極については総説 ${ }^{153)}$, 粗面効果 ${ }^{154)},+2.0 \mathrm{~V}$ におよぶ陽極分極用白金回転電極 ${ }^{155)}$ ，分極滴定用アンチ

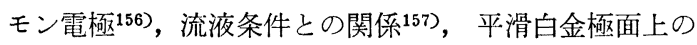
酸素層の研究158), 液体アンモニア中での利用 ${ }^{159)}$, 表面 状態の連続的な更新処理 ${ }^{160) 161)}$, 電流-電位-時間の三次

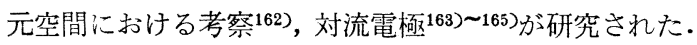

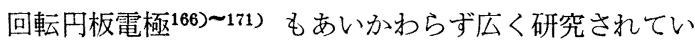
る.

ポーラログラフ装置については, 日本 ${ }^{172)}$, アメリカ173), ヨーロッパ174) における現状についての総説がある。ま た，連続分析装置175) についての総報もある. ボルタン メトリー用の万能型装置176) 178), タスト・ポーラログラ

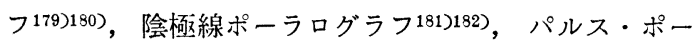
ラログラフ ${ }^{183)}$, anodic stripping 用装置 ${ }^{184)}$, 交流ポー ラログラフ ${ }^{185)}$, 示差ポーラログラフ装置 ${ }^{186)}$, 連続自動

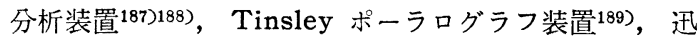
速記録装置 ${ }^{190)}$, 電圧断続法191), $i R$ 補(償回路 ${ }^{192)(93), ~}$ 残

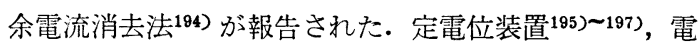

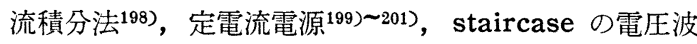
形を用いる装置 ${ }^{202)}$ が報告された．また，溶存酸素の測 定装置 ${ }^{203)}$, 特性の異なる毛細管を使用できる感度調節装

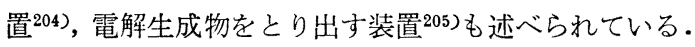

\section{$4 \cdot 4$ 理 論}

理論の詳細は「電気化学の進歩」にゆずり,ここでは
比較的に分析化学と関連の深い話題について述べよう. 多くの価値ある総説が発表され，電極反応の活性化熱の 物理化学的裏づけ206), イルコビッチ式の修正理論の最終 的総括 ${ }^{207)}$, 電流-時間曲線の解析 ${ }^{208)}$, 電極過程の速度論 209), 電極反応に前置 (反応電流) または後置 (接触電流) された化学反応を伴う拡散過程の諸理論の集大成 ${ }^{210)}$, 相 界面に拈ける電気化学反応の諸段階211)がそれぞれその 道の権威によってまとめられた。 また, 電流-電位曲線 から電極反応のパラメーター $\left(k_{s}\right.$ と $\left.\alpha\right)$ を求める方 法212)213) が述べられた。電流-時間曲線についても報 告214) 216) があり, 前の滴における電解による希薄化効 果がシュリーレン法217により研究され, 泳動電流 ${ }^{218)}$ の 理論が提出された. クロノポテンシォメトリー2192220) と stripping221)222) についても，拡散の問題としての厳密

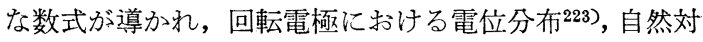
流時の濃度分極の理論224)がある. 反応電流については, 総報 ${ }^{225)}$, 臭素酸226), 過塩素酸イオンの Mo(VI) による 接触電流227が研究された。

交流ポーラロクラフィー理論については, 電解整流と 電極過程の関係 ${ }^{228)}$, 第 3,4 高調波 229$), U(V)$ の不均 一化 ${ }^{230)}, \mathrm{T} 1-\mathrm{T} 1+$ 系の定数 ${ }^{231)}$, アドミッタンス-周波数 スペクトル232), 金属極の挙動 ${ }^{233) か ゙ あ る . ~}$

界面活性凧の電極面への吸着234) について総説があ り, 陰イオンの還元に及ぼすプサイ効果 ${ }^{235)}$, 二重層の構 造236), 吸着と電極反応237)について力作がまとめられた. 二重層の構造についても多くの研究があり 238) 240), ノニ オン活性剂242), そのほかの電流-時間曲線に及ぼす効,

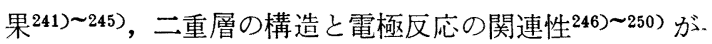
注目を集めている.

極大については,液の流動 ${ }^{251)}$, 外部抵抗 ${ }^{252)}$, 極の形 253$)$, 尿素-ホルムアルデヒド縮合体の抑制効果 ${ }^{254)}$, 温度など の影響255)が研究された。

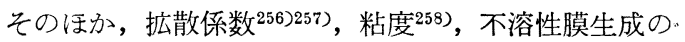
影響 ${ }^{259)}$, 水素電極の拡散分極 ${ }^{260)}$, 接触的水素発生 ${ }^{261)}$, 多孔性電極の分極 ${ }^{262)}$, 鉄の還元機構 ${ }^{263)}$, オッシロポーラログラムの積分法 ${ }^{264)}$, 荷電電流 ${ }^{265}$ が研究された.

\section{5 各論}

無機ポーラログラフィー全般 ${ }^{266)}$, 無機復極剂の構造と 電極反応機作 ${ }^{267)}$, 錯体 ${ }^{268)}$, 試料処理法 ${ }^{269)}$, 有機試薬の.

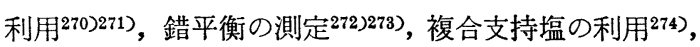
4 級アンモニウム塩の精製275) が権威者によりまとめら れた。

錯体については, $\mathrm{Cu}(\mathbb{I})$-スレオニン276), $\mathrm{Pb}(\mathrm{I})-$ $\mathrm{EDTA}^{277)}$ ，硫酸ニッケル278), Cd (I )とコウシ酸 ${ }^{279), ~ お ~}$ 


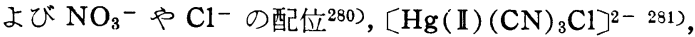
$\mathrm{Hg}$ (II) とアルキルアミンの錯体 $\left.\left.{ }^{282}\right), \mathrm{Hg}(\mathbb{I})\left(\mathrm{S}_{2} \mathrm{O}_{3}\right)_{x}{ }^{283}\right)$ が研究され, イオン交換反応 ${ }^{284)}$, オルトリン酸, 覀硫酸 などの解離速度定数 ${ }^{285}$, 接触電流を利用する 安定度定 数の測定 ${ }^{286)}$, シュウ酸286a), グリシン287), DCTA ${ }^{288)}$, シ チオカルバミン 289)のキレート,水酸化インジウムの溶解 度 ${ }^{290)}$, ビスマス-EDTA の安定度定数291)が述べられた。

また, ケイ素, モリブデンのヘテロポリ酸292), ニトロ ソフェノール 293), トリェチレンテトラミン294), ヘキサリ ン酸 ${ }^{295)}$, ピロおよびトリリン酸 ${ }^{296)}$, en シシュウ酸の混 合配位 ${ }^{297)}$, ギ酸塩 ${ }^{298}$, 乳酸, そのほか2999の錯体が研究 された.コバルトやニッケルのシスティン錯体の接触水 素波を利用して $10^{-8} M$ の重金属を定量する試み(300), 有 機アミン301) の利用がのベられ，アマルガム・ポーラロ

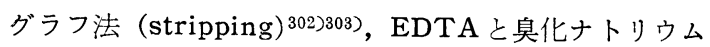
の混合液中で $\mathrm{Sn}(\mathbb{V})$ と $\mathrm{Pb}(\mathbb{I})$ の同時定量 ${ }^{304)}$ が行 なわれた. 無機交流ポーラログラフィーについては, 11 種の普通イオンについて, 支持塩が広範に検討され た

以下, 元素別にのベよう. Ag のシアン錯体 ${ }^{306)}$ につ いては, 過剩の $\mathrm{CN}^{-} を \mathrm{Ni}^{2+}$ で除くと, 真の波が得 られ, また白金極上 ${ }^{307)}$ の析出, テトラヒドロフラン中

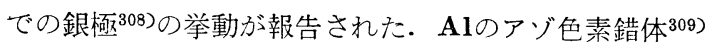
はオッシログラフ法により定量され，シロキサン中 ${ }^{310}$ のアルミニウムが定量された. As の微量定量311)とアン

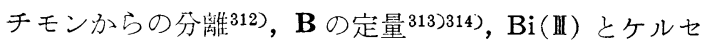
チンの錯体 ${ }^{315)}$, 定量法 ${ }^{316)}$ が述べられた. Cd について は, $\mathrm{N}_{3}$ - 317 ) および $\mathrm{NTA}^{318)}$ との錯体, 硫酸十ヨウ化力 リウムの溶媒 ${ }^{319}$ り使用がある. Co とヒスチジン320)，リ ポ酸 ${ }^{321)}$, システィン ${ }^{322)}$ の錯体, $\left[\mathrm{Co}(\mathrm{CN})_{4}\left(\mathrm{SO}_{3}\right)_{2}\right]^{5-323)}$, カルボン酸とアンモニアを配位したもの324), シスチンと の相互作用 ${ }^{325)}$ ，アミノ酸やたん白質共存時の還元波 ${ }^{326)}$, コバルトーヒスチジンと酸化窒素の反応 ${ }^{327)}$, さらにコバ ルトの微量定量 ${ }^{328)}$ がある. Cr については, 定量法329) :330) のほかに, クロム酸の 還元機構 ${ }^{331)}$, 被膜生成 ${ }^{332)}$, $\operatorname{Cr}(\mathbb{I I})$ のクロロ ${ }^{333)}$, ロダン ${ }^{334)}$, ハロゲン・ペンタアンミ ン錯体 ${ }^{335}$ の研究がされた. Cu は ${ }^{3} \mathrm{H}$ でラベルしたアン トラニル酸との反応 ${ }^{336)}$, 炭酸水素カリウム支持塩 ${ }^{337)}$ で の波, アセトン中のクロロ錯体 ${ }^{338}$, シアヌル酸 ${ }^{339}$, モノ， ジ，トリエタノールアミン340)との錯体が，また Ce(IV)Ce $(\text { III })^{341)}$ は硫酸中で研究された. Fe は solochrome violet $\mathrm{RS}$ 錯体 ${ }^{342)}$, フェリシアン ${ }^{343)}, \mathrm{Ga}$ の CyDTA キレート ${ }^{344)}, \mathrm{NaClO}_{4}{ }^{345)}$ 少よび酢酸緩衝液中 ${ }^{346)}$ の $\mathrm{Ge}(\mathrm{IV}), \mathbf{H g}(\mathbb{I})$ とアルキルアミン347), チ才硫酸348) 錯 体が検討された.Inはトリヒドロキジルグルタル酸 ${ }^{350)}$,

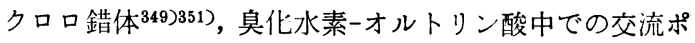
一ラログラフ法352), スズからと ${ }^{353)}$, 鉛, カドミウムか ら ${ }^{354)}$ の分離が報告され, Ir のクロロ錯体 ${ }^{355)}, \mathbf{K}^{356}$, アゾ 染料によるランタニドの定量 ${ }^{357)}$ がのべられた. Mn に ついてはマンガン酸イオンの酸化 ${ }^{358}, 2+\rightleftarrows 3+$ 系 ${ }^{359)}$, $\mathrm{Mn}$ (VII) 共存時の $\mathrm{MnO}_{4}{ }^{2-}$ の定量 ${ }^{360)}$, スルホサリチル 酸を利用する分析 ${ }^{361)}$ がある. Mo について注クロロ錯 体 ${ }^{362)}$, イソポリ酸363), $\mathrm{MoS}_{4}{ }^{2-}{ }^{364)}$, アセチルアセトン 抽出定量 ${ }^{365)}, \mathrm{ClO}_{4}^{-}$と $\mathrm{NO}_{3}-$ の接触電流366)367), リン 酸やヒ酸とのヘテロポリ酸368)が研究された。 Nbは, タ ンタルふららの分離 ${ }^{369}, \mathrm{EDTA}$ キレート 3703371), Ni は脱 水和の反応電流 ${ }^{372)}$, クマリン錯体 ${ }^{373)}$, オキシ酸374), 交 流波 ${ }^{375)}$, チロンを用いるオッシログラフ法376) が研究さ れた. Os は +6 と +4 の状態377, $\mathbf{P}$ は $\mathrm{PH}_{4}$ の還

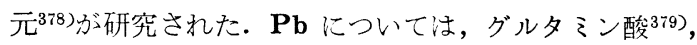
リン酸 ${ }^{380)}$ 中の挙動, イオン交換分離後の定量 ${ }^{381)}$, 陰極 線ポーラログラフ法382) などがあり, Pd ${ }^{383)}$ は EDTA キレート, $\mathbf{P t}^{384)}$ はクロロ錯体, $\mathbf{R e}^{385)}$ は接触波, $\mathbf{R h}$ はシュウ酸386)，ブロモ387)，チオシアン388) 荠体ぶ, Ru はクロロ ${ }^{339)}$, シュウ酸390) 錯体が研究された. 遊離の S の波に及ぼす金属イオンの影響 ${ }^{391)}, \mathrm{SOCl}_{2}{ }^{392)}$ の定量, $\mathrm{Sb}(\mathbb{I I})$-EDT ${ }^{393)}, \mathrm{Sc}\left(\mathrm{H}_{2} \mathrm{O}\right)_{x^{394)}, \mathrm{Se}}$ はジセ レンジ酢酸395) の還元のほか, 微量定量例396; 400) が多 い. Sn は,ピロガロール錯体 ${ }^{401)}$, 高純度銅中の定量402), イオン交換分離 ${ }^{403)}$, ギ酸塩中の挙動 ${ }^{404)}$, stripping 法

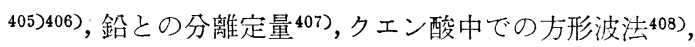
複合支持塩法 ${ }^{409)}$ が検討された. Ta (V)-EDTA ${ }^{410)}$, Th(N) のヨウ素酸カリウム411)，および銅-EDTA ${ }^{412)}$ に よる間接定量, アセトニトリル中の挙動 413$), T i$ と +4 の状態 ${ }^{414)}, \mathrm{T}(\mathrm{I}(\mathrm{I})$ のアセトニトリルー水混合溶 媒中の挙動 ${ }^{415)}$, 被吸着性と界面活性剤の効果 ${ }^{416)}$, 卜リ リン酸塩を用いる定量 ${ }^{417)}$, 電気化学マスキングによる分 離定量 ${ }^{418)},+3 \rightleftarrows+1$ の系419) が研究された。Uについ

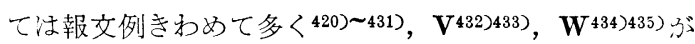
研究された。 Zn は, NTA436)，アルカリ水溶液 437 (438), グルタミン酸塩 ${ }^{3} 99$ ) 中の挙動が検討され，イオン交換分 離440)，アマルガム法441)442) で定量され，Zr 沈，エタノ ール443) と溶融塩444) 中で定量された． $\mathrm{O}_{2}$ については, 電極金属它酸化する効果 ${ }^{445)}$, 過酸化水素の不均一化によ り第 1 波が第 2 波より高(性質446)447), 特殊電極 4 48), 多

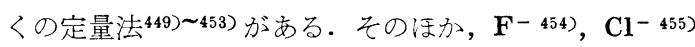
${ }^{456)}, \mathrm{I}^{-457) 458)}, \mathrm{IO}_{3}{ }^{-}$と $\mathrm{IO}_{4}{ }^{-459)}, \mathrm{CN}^{-460)}, \mathrm{SCN}^{-461)}$ が報告された。 


\section{6 応用 分 析}

冶金学 ${ }^{462)}$, 鉱物学その他463), ならびに化学工業464)の 分野における最新の応用についてすぐれた総説が刊行さ れた. 一方，応用分析におけるポーラログラフ法の活用 の研究もあいかわらず活発である.

地金および合金中の微量元素の定量：高純度アルミニ ウム中の $10^{-6} \%$ 程度の鉛定量のため，濃縮法や妨害元 素の除去についての検討がなされた465)。 アルミ合金に ついては, 銅, 鉄, 鉛, ニッケル, 亜鉛, カドミウム, ナトリウム，クロム，スズの定量法についての検討ぶな され ${ }^{466)}$, 銅, 亜鉛, マンガン, 鉄, ニッケルの定量 ${ }^{467), ~}$ カテコリンか Magneson II を用いる銅, 鉄, 鉛の定 量 ${ }^{468)}$, 方形波ポーラログラフ法による銅, 覀鉛, 鉄の定 量469) が報告された. 純金中のビスマス, カドミウム, 銅, 二ッケル，鉛，业鉛，鉄の定量は，臭化水素酸性溶 液から金のみをあらかじめ有機溶媒で抽出分離し，また， 支持電解質を種々变えることにより可能となり470), ベリ リウム中のアルミニウムは Superchrome garnet Y の存在で, 陰極線ポーラログラフ法で定量された471). カドミウム中のタリウムは $0.003 \%$ をで定量でき, その とき共存する銅のマスク剂も検討され472), 亜鉛定量はあ らかじめ大部分のカドミウムをエーテルで抽出分離する 方法が報告されだ73)。銅中のカドミウム注銅をあらか じめ酸性溶液から金属亜鉛で還元分離することにより定 量でき474),ガリウム中のインジウムはインジウムを四塩 化炭素で抽出分離したのち475)，またゲルマニウム中の 銅, 鉛, 銀, ニッケルは地金を四塩化ゲルマニウムとし て蒸留分離したのち，オッシログラフ法476) で定量され た. 鉄, 鋼, そのほかについては, 㓌極線ボーラログラ フ法が純鉄，軟鋼，低合金鋼中のスズ477)，鉄，鋼中の 銅, 鉛, スズ, アルミニウム, ビスマス, ニッケル, コ バルト478), フェロマンガン中のアンチモン, 銅, 鉛の定 量479)や鋼中の鉄孛䣷酸ーイソブチルで抽出後, Curry 改 良法による銅, 鉛の同時定量480) に応用され, フェロバ ナジン, フェロジルコンおよびフェロチタンの各合金中 のアルミニウムが鉄, バナジン, ジルコニウム, チタン をクペロンで抽出分離後 Pontachrom violet 法で定量 され481)，また鋳鉄中のアンチモン482)，ステンレス鋼中 のスズ483), 高速度鋼中のバナジン484), フェライト中の ニッケル, 亜鉛, マンガン, 鉄485) やマンガン, 鉄486)の 諸定量, マンガン一亜鉛フェライトおよびニッケル-亜鉛 フェライト中のニッケル, 业鉛の分析をキレート法と比 較した研究487) が報告された. インジウム中のカドミウ ム定量は, CyDTA, 硝酸トリウムの添加 ${ }^{488)}$, 純鉛中の
銅, ビスマスの同時定量は NTA 共存 ${ }^{489)}$, 鉛中のビス マス, スズ, ヒ素の同時定量は二酸化マンガンによる共 沈分離 ${ }^{490)}$, 製鍊鉛中のアンチモン定量は硝酸一硫酸溶解 後, 硝酸を駆遂491) することにより解決した.タンタル およびその酸化物中の二オブ，チタン，鉄定量には支持 電解質にピロリン酸 ${ }^{492)}$, テルル中のヨウ素定量には $I_{2}$ 蒸留分離法493) が応用され, テルル中の鉛, 銅定量には 適当な支持電解質が工夫された494). ウラン中の鈆の交 流ポーラログラフ法による定量結果法比色法上よく一致 し495), 亜鉛, ガリウム, アンチモン, ヒ素中の鉛をアマ ルガム法により定量する際の地金の妨害を除く方法496), ジルコニウム合金中のニオブ定量 ${ }^{497)}$, ジルコニウム, 八 フニウム中の銅, 鉛, モリブデン, タングステン, 亜鉛 を方形波ポーラログラフ法で直接定量できる支持電解質 の研究498などが報告されている.

岩石, 鉱物中の微量元素の定量: 鉱石中の鉄, マンガ ン, チタンは,トリエタノールアミンー水酸化ナトリウム または，EDTA-酢酸緩衝液の支持電解質を用いるオッ シロポーラログラフ法499) だ, アルミニウムは, Al-dye 錯体の還元電流志利用する普通ポーラログラフ法および オッシログラフ法500)で, またウランもオッシログラフ法 501)で, それぞれ定量された. さらにドロマイト石灰岩中 の鉛, カドミウム, 要鉛502), 岩石の標準試料である G$1, \mathrm{~W}-1$ 中の鉛503) の定量にもオッシログラフ法ぶ空用 された。各種鉱石中のタリウムとカドミウム梁 $2 \%$ 硫 酸-7\% オルトリン酸および $1 M$ 硫酸アンモニウムの支 持電解質を用いて交流ポーラロ法で定量された504). チ タンージルコニウムおよび鉄の鉣石中のチタン, 鉄 50 万), 岩石中の力ドミウム, 銅, 鉛, ビスマス, 亜鉛506) の定 量, 鉣石中のタリウムをDDTCで抽出後, さらに共存 する鉛，ビスマスをそれぞれ硫酸䘏，オキシン塩として 分離後定量する方法507, 鉱物抢よび天然水中のウラン文 硝酸塭にしてエーテルで抽出分離後, 標準添加法で定量 する方法 ${ }^{508)}$, ウラン鉱洗鉱液中の七素, セリウム, コバ ルト, 銅, ニッケル, 亜鉛を定量した例 ${ }^{509}$, 岩石, 鉣石 中のモリブデン定量を比色法と比較した研究510), ケイ酸 塩中のヒ素, アンチモンの定量 ${ }^{511)}$, 岩石中のカドミウム をジチゾンー四塩化炭素で抽出分離後定量した研究512)な どが報告された。

生体および食品中の微量元素定量：生体中の七素, ア ンチモンをキサントゲン酸塩として四塩化炭素に抽出分 離後定量する方法 ${ }^{513)}, 1 M$ 水酸化アンモニウム-䘏化ア ンモニウムの支持電解質を用いる植物中の銅, 亜鉛, マ ンガンの定量 ${ }^{514)}$, 各種生体中の亜鉛の迅速定量 ${ }^{515)}$, 静 止電極を用いる体液中の酸素の定量 ${ }^{516)}, 0.05 \mathrm{ml}$ の微少 
試料でよい血清中のカルシウム定量 ${ }^{517)}$, 人血中の 鉛の anodic stripping 法による定量 ${ }^{518)}$, 血液中の亜鉛をジ チゾンで抽出分離後陰極線ポーラログラフ法で定量する 方法ならぴにその操作中の損失, 污染を ${ }^{65} \mathrm{Zn}$ を用いて 調べた研究519)が報告された，尿中のセレン520)，ブドウ 酒中の銅, 覀鉛, 鉄, 鉛 521$)$, K1000 単掃引陰極線ポー ラログラフ法による食料品中の銅, 鉛, スズ, 亜鉛522), 方形波ポーラログラフ法によるグルタミン酸ナトリウム 中の鉛, 亜鉛, カルシウム523)の定量法も報告された.

その他：銅錯体の不安定度定数とその試薬の放射性疾 患予防剂との関係 ${ }^{524)}$, 放射化分析に括けるポーラログラ フ法の役割 525$)$, 石油分析の際の問題点や無機成分のおの おのの定量法についての総説526) や交流ポーラログラフ 法によるガソリン中の遊離イオウの迅速定量法527), 石油 および石油製品中のイオウおよびイオウ化合物と, 使用 したオイル中の金属粉の分析 ${ }^{528)}$,才イルおよびオイル製 品中のイオウおよびイオウ化合物の分析 ${ }^{529)}$, 方形波ポー ラログラフ法による接触改質法の原料中の $\mathrm{ppb}$ 程度の 銅, 鉛の定量530) について報告された。エタノール中の 覀鉛531)，フィルターで捕集した空気中のマンガン，クロ ム, 鉄 ${ }^{532)}$,つり下げ電極を用いた水中の銅, 鉛, カド之 ウム533)，パルスポーラログラフ法による海水中のウラ ン534) についての諸定量法，水および固体から濃縮後の ウラン定量の際の誤差 ${ }^{535)}$, 陰極線ポーラログラフィーの 海洋学の分野への応用 ${ }^{536)}$, ペニシリン, オキシテトラサ イクリン中の重金属537）や工業用安息香酸巠鉛538）の分 析, $\mathrm{EDTA}$ と $\mathrm{SO}_{4}{ }^{2-}$ を用いるバリウム, ストロンチウ ム, カルシウムの間接定量 ${ }^{539)}$, インジウムとスズ540), ヒ 素とアンチモン 541)542) の同時定量，塩化ナトリウムと塩 化カリウムの結晶中のバリウム，ストロンチウム ${ }^{543)}$, 磁性酸化鉄電極中の亜鉛, 銅, 鉛 ${ }^{544)}, \mathrm{Mg}\left(\mathrm{NO}_{3}\right)_{2}-工$ タノール共存燃焼法を利用した活性炭中の鉛545), mill products 中の金 ${ }^{546)}$, 金メッキ液中のインジウム, コ バルト, ニッケル547) ならびにカドミウム, コバルト, 銅, 亜鉛, 鉄, スズ, クロム ${ }^{548)}$, キナリザリンの還元波高 がアルミニウムの存在で減少することを利用した土壤中 のアルミニウム549）の各定量法や，方形波ポーラログラ フ法によるヒ化ガリウム中のビスマス, インジウム, カ ドミウム550), Superchrome garnet Y を用いた単掃引 オッシログラフ法によるトリウム化合物中のアルミニウ ム551) の定量について報告された. $\mathrm{NO}_{2}-$ と $\mathrm{NO}_{3}{ }^{-552)}$ ， $\mathrm{NO}_{2}{ }^{-553)}$, 土壤中の $\mathrm{NO}_{3}{ }^{-554)}$, 硝安石灰肥料中のア ンモニア体窒素と硝酸体窒素555) の定量, 遊離の七素を $\mathrm{Cl}_{2}$ と二酸化イオウで処理して定量する方法 ${ }^{556)}$ やケイ モリブデン酸のうち $\gamma$ 型のみがポーラログラフ的に活性
であることを調べ，それを利用するケイ素の定量 ${ }^{557) に ~}$ ついての研究が報告された.

\section{交 献}

交献中に “Progress” とあるのは, P. Zuman, I.M. Kolthoff, eds., "Progress in Polarography", Interscience (1962) の 略称である。

1) 武者宗一郎: “ポーラログラフィー”('61), (東京化学同人); 2) H. Schmidt, M. von Stackelberg: "Die neuartigen polarographischen Methoden, ihr Prinzip und ihre Möglichkeiten", (1962), (Verlag Chemie); 3) P. Zuman, I. M. Kolthoff, eds.: "Progress in Polarography", Vol. 1 and 2 (1962), (Interscience); 4) 藤永太一郎, 丸山正生編: “ポーラログラフィー”化学の領域增刊 50 号, 第 1 集, 交流ポーラロ グラフィー (1962), (南江堂)；5）電気化学協会編：電気化学の進 歩 ('62); 6) M. Heyrovska: Progress, 1 ('62); 7) P, Zuman: ibid., $583\left({ }^{\prime} 62\right)$; 8) 武者宗一郎：ポーラログラフ 1ー, 9, $105\left({ }^{\prime} 61\right)$; 9) 安盛善一: 同上, 9, $17\left({ }^{\prime} 61\right)$; 10) 安盛善一: 同上, 10, 192 ('62).

11) 永井外代士: 同上, 9, 8 ('61); 12) 岡 正太郎: 同上, 10, 198 ('62); 13) H. Berg: Angew. Chem., 73, 495 ('61); 14) H. W. Nürnberg, M. von Stackelberg: J. Electroanal. Chem., 2,181,350 ('61); 15) H. W. Nürnberg: $Z$. anal. Chem., 186, 1 ('62); 16) A. I. Lopushinskaya, A. B. Pamphilova: Uspekhi Khim., 30, 386 ('61); 17) Ya. I. Turyan, A. M. Murenkov: Zavod. Lab., 27, 507 ('61) 18) A. Braunwalder, A. Grubenmann, F. Hügli: Chimia，15，461 ('61)；19）永井外代士：ポーラログラフィー, 9, 8 ('61); 20) R. Neeb: Angew. Chem., 74, 203 ('62); Intern. Ed., 1, 196 ('62).

21) J. W. Olver, J. W. Ross: Anal. Chem., 34, 791 ('62); 22) J. Dévay, I. Labody, A. Galdy: Magyar Kem. Folyoirat, 67, 21 ('61); 23) D. Glietenberg, G. van Riesenbeck, H. W. Nürnberg: Z. anal. Chem., 186, 102 ('62); 24) Y. Mashiko, N. Hosoya, K. Ito: Rev. Palarography, 10, 33 ('62); 25) W. Kemula: Progress, $397\left({ }^{\prime} 62\right)$; 26) 中川I 元吉: ポーラログラフィー, 9, $194\left({ }^{\prime} 61\right)$; 27) T. Erdey-Gruz, J. Devay, R. Szegedi: Magyar Kem. Folyoirat, 67, 244 ('61), 68, 140 ('62); 28) R. Narayan: Electrochim. Acta, 7, 225 ('62); 29) H. B. Mark, E. M. Smith, C. N. Reilley: J. Electroanal. Chem., 3, 98 ('62); 30) 岡正太郎: 日化, 82, 1202, $1206\left({ }^{\prime} 61\right)$.

31) M. Shinagawa, H. Nezu, T. Yamada: Rev. Polarography, 10, 164 ('62); 32) N. T. Kudryavtsev, R. Yu, Bek, M. R. Tarasevitsh: Zhur. Fiz. Khim., 35, 1507('61); 33) G. C. Barker: Progress, 411 ('62); 34) K. Itsuki, K. Nishino: Rev. Polarography, 10, $41\left({ }^{\prime} 62\right)$; 35) R. M. Johnson: Lab. Practice, 11, 534, 612 ('62); 36) K. Eckschlager: Collection, 27, 1521 ('62); 37) 石橋雅義, 藤 永太一郎, 伊豆津公祐：日化, 82, $206\left({ }^{\prime} 61\right)$; 38) K. D. Omarova: Zavod. Lab., 27, 55 ('61); 39) T. Fujinaga, K. Izutsu: Rev. Polarography, 9, 36 ('61); 40) B. Breyer: Progress, 487 ('62).

41) H. Imai: Rev. Polarography, 10, 209 ('62); 42) B. Breyer: ibid., 9, 125 ('61); 43) 神原富民: ポーラログラ フィー, 9, 149 ('61); 44) 端野朝康; 同上, 10, 23 ('62); 45) T. Kambara, T. Ishii: Rev. Polarography, 9, 30 ('61); 46) W. H. Reinmuth, D. E. Smith: Anal. Chem., 33, 964 ('61); 47) H. H. Bauer, W. H. Reinmuth, D. E. Smith: ibid., 1803; 48) B. Breyer: Australian J. Science, 23, 225 ('61); 49) B. Breyer, H. H. Bauer, J. R. Beevers: Australian J. Chem., 14, 479 ('61); 50) T. Biegler: ibid., 15, 34 ('62).

51) H. H. Bauer: ibid., 15, 13 ('62); 52) S. K. Rangarajan, K. S. G. Doss: ibid., 14, 458 ('61); 53) 商 藤第義: 日化, 82, 212 ('61); 54) M. Kodama: Bull. Chem. Soc. Japan, 34, 714 ('61); 55) H. H. Bauer: J. Electro- 
ananl. Chem., 2, 66 ('61); 56) H. H. Bauer: ibid., 3, 150 ('62); 57) S. K. Rangarajan, K. S. G. Doss: ibid., 3, 217 ('62); 58) H. H. Bauer, P. J. Elving: ibid., 2, 53 ('60 61); 59) J. W. Hayes, H. H. Bauer: ibid., 3, 336 ('62); 60) D. E. Walker, J. R. Alden: Anal. Chem., 33, 308 ('61).

61) D. E. Smith, W. H. Reinmuth: ibid., 33, 482 ('61); 62) J. Llopis, M. Vazquez: Electrochim. Acta, 6, 177 ('62); 63) S. K. Rangarajan, K. S. G. Doss: ibid., 7, 201 ('62); 64) R. Neeb: Z. anal. Chem., 186, 53 ('62); 65) M. Rehbach, J. H. Sluyters: Rec. trav. chim., 80, 469 ('61); 66) A. N. Frumkin, B. B. Damaskin: J. Electroanal. Chem, 3, 36 ('62); 67) M. Senda, I. Tachi: Rev. Polarography, 10, $79\left({ }^{\prime} 62\right)$; 68) M. Senda, P. Delahay: J. Phys. Chem., 65, 1580 ('61); 69) L. Llopis, M. Vazquez: Electrochim. Acta, 6, 167 ('62); 70) F. von Sturm, M. Ressel: Microchem. J., 5, 53 ('61). 71) O. Fischer, O. Dracka, E. Fischerova: Collection, 25, 323 ('61); 72) Y. Takemori: Rev. Polarography, 9, 246 ('61); 73) A. C. Testa, W. H. Reinmuth: Anal. Chem., 33, 1320 ('61); 74) A. C. Testa, W. H. Reinmuth: ibid., 33, 1324 ('61); 75) O. Dracka: Collection, 26, 2144('61); 76) T. Fujinaga: Progress, 201 ('62); 77) 伊豆津公祐: 日化, 82, 703 ('61); 78) 伊豆津公鿆：同上, 82, 1500, 1503 ('61); 79) J. Vogel: Progress, 429 ('62); 80) R. Kalvoda: ibid., 449 ('62).

81) H. M. Davis, H. I. Shalgosky: J. Polarog. Soc., 1, 12 ('60); 82) J. Horyna, V. Jehlicka: Collection, 27, 1326 ('62); 83) R. Kalvoda, Ch. Stockmann: Chem. Listy, 55, 477 ('61); 84) D. Kalab: Experientia, 17, 275 ('61); 85) A.P. Mead, A. Parker, E.A. Terry: Nuclear Sci. Abstr., 16, 357 ('62); 86) Y. Saito, K. Okamoto: Rev. Polarography, 10, 227 ('62); 87) L. Ya. Shekun: Zhur. Fiz. Khim., 36, 455 ('62); 88) E. Görlich, J. Srzednicky, Z. Kowalski: ibid., 36, 449 ('62); 89) Ya. P. Gokhstein, Gao Tsai-shen: ibid., 35, 1611 ('61); 90) G. Gavioli, P. Papoff: Ricerca Sci., IIA, 31, 193 ('61).

91) H. M. Davis, R. C. Rooney: J. Polarog. Soc., 8, 25 ('62); 92) J. H. Sluyters: Rec. Trav. Chim., 81, 297 ('62); 93) P. Delahay: Anal. Chim. Acta, 27, 90, 400 ('62); 94) P. Delahay: Anal. Chem., 34, 1267 ('62); 95) 池田重良：ポーラログラフィー，10，51 ('62); 96) K. Schwabe: Progress, 333 ('62); 97) G. Schöber, V. Gutmann, E. Nedbalek: Z. anal. Chem., 186, 115 ('62); 98) G. Schöber, G. Rehak: Monatsh. Chem., 93, 445 ('62); 99) H. Dehn, V. Gutmann, G. Schöber: ibid., 93, 453 ('62); 100) W. Hubicki, M. Dabkowska: Anal. Chem., 33, 90 ('61).

101) W. B. Schaap, R. F. Conley, F. C. Schmidt: ibid., 33, 498 ('61); 102) P. J. Elving, J. M. Markowitz, I. Rosenthal: J. Phys. Chem., 65, 680 ('61); 103) D. E. Sellers, G. W. Leonard Jr.: Anal. Chem., 33, 334 ('61); 104) P. Arthur, R. H. Vanderkam: ibid., 33, 765 ('61); 105）吉沢四郎：ポーラログラフィー, 9, 2 ('61); 106) G. Danner, M. Rey: Electrochim. Acta, 4, 274 ('61); 107) R. Littlewood: ibid., 3, 270 ('61); 108) N. G. Khovnik, V. V. Vaschenko: Zhur. Fiz. Khim., 35, 580 ('61); 109) D. L. Maricle, D. N. Hume: Anal. Chem., 33, 1188 ('61); 110) E. Schmidt: Electrochim. Acta, 7, 179 ('62).

111) I. D. Pantshenko, G. W. Shilina: Dopodivi Akad. Nauk Ukr. RSR, 205 ('61); 112) D. Inman, J. O'M. Bockris, E. Blomgren: J. Electroanal. Chem., 2, 506 ('61); 113) E. Blomgren, D. Inman, J. O'M. Bockris: Rev. Sci. Instr., 32, 11 ('61); 114) W. Kusmovitch: Dopodivi Akad. Nauk. Ukr. RSR, 44 ('61); 115) W. Kusmovitch: ibid., 344 ('61); 116) I. I. Naryshkin, V. M. Mogilev: Zhur. Prikl. Khim., 34, 2104 ('61); 117) I. I. Naryshkin, A. E. Bazhenov: ibid., 34, 2102 ('61);
118) L. E. Topol, R. A. Osteryoung: J. Phys. Chem., 66, 1587 ('62); 119) J. J. Egan: ibid., 65, 2222 ('61); 120) D. G. Hill, M. Blander: ibid., 65, 1866 ('61).

121) K. M. Kalabalina, Yu. K. Delimarskii: Ukrain. Khim. Zhur., 27, 770 ('61); 122) Z. P. Zagorski: Progress, 549 ('62); 123) H. Berg: Rev. Polarography, 9, 25 ('61); 124) G. Anders, K. Schwabe: Z. Chem., 1, 223 ('61); 125) W.J. Blaedel, J.H. Strohl: Anal. Chem., 33, 1631 ('61); 126) R. M. Parkhurst: ibid., 33, 320('61); 127) J. Hejduk, M. Sula, E. Rechziegel: Chem. Listy, 56, 539 ('62); 128) S. N. Das, D. J. G. Ives: J. Chem. Soc., 1619 ('62); 129) I. M. Kolthoff, Y. Okinaka: Progress, 357 ('62); 130) H. P. Raaen, H. C. Jones: Anal. Chem., 34, 1594 ('62).

131) W. D. Cooke, M. T. Kelley, D. J. Fisher: ibid., 33, 1209 ('61); 132) I. E. Bykov: Zavod. Lab., 28, 249 ('62); 133) H. P. Raaen: Anal. Chem., 34, 1714 ('62); 134) B. Ya. Kaplan, P.M. Chigirev: Zavod. Lab., 28, 101 ('62); 135) R. Briggs, G. Knowles: Analyst, 86, 603 ('61); 136) A. Littlewood: ibid., 86, 359 ('61); 137) R.J. Newcombe, R. Woods: Trans. Faraday Soc., 57, 130 ('61)；138）沖中裕: ポーラログラフィー, 9, 41 ('61); 139) M. Breant, J. C. Merlin: Compt. rend., 252, 2410 ('61); 140) J. Horyna, V. Jehlicka: Collection, 27, 1326 ('62).

141) J. Riha: Progress, 383('62); 142) L. N. Vasileva, E. N. Vinogradova: Zavod. Lab., 27, 1078 ('61); 143) A. G. Stromberg, E. A. Stromberg: ibid., 27, 3 ('61); 144) M. S. Zacharov, A. G. Stromberg: ibid., 28, 13 ('62); 145) I. Shain, K. J. Martin: J. Phys. Chem., 65, 254('61); 146) I. Shain, K. J. Martin, J. W. Ross: ibid., 65, 259 ('61); 147) K. Micka: Chem. Listy, 55, 474 ('61); 148) F. von Sturm, M. Ressel: Z. anal. Chem., 186, 63 ('62); 149) M. J. Bourzeix, I. Robert, M.L. Viet: Compt. rend., 254, 3532 ('62); 150) A. Y. Gokhstein, Y. P. Gokhstein: Zhur. Fiz. Khim., 36, 652 ('62).

151) W. L. Underkofler, I. Shain: Anal. Chem., 33, 1966 ('61); 152) R. Neeb: Z. anal. Chem., 180, 161 ('61); 153) R. N. Adams: Progress, 503 ('62); 154) I. Rousar: Collection, 25, 1867 ('61); 155) J. W. Loveland, G. R. Dimeler: Anal. Chem., 33, 1196 ('61); 156) E. Bishop, G. D. Short: Analyst, 87, 467 ('62); 157) J. Jordan, R. A. Javick: Electrochim. Acta, 6, 23 ('62); 158) W. Böld, M. Bretter: ibid., 5, 145 ('61); 159) R. N Hammer, J. J. Lagowski : Anal. Chem., 34, 597 ('62); 160) Ya. I. Turyan: Zavod. Lab., 28, 98 ('62).

161) F. Strafelda, D. Kozak: Collection, 26, 3168 ('61); 162) Yu. K. Delimarsky, A. V. Gorodisky: Zhur. Fiz. Khim., 35, 1091 ('61); 163) 尾崎德郎, 中山隆男: 日化, 82, 46 ('61); 164) R. C. Kapoor, S. K. Tiwari: Z. anal. Chem., 183, 24 ('61); 165) P. Bersier, J. Bersier, R. Chaperon, F. Hügli: Helv. Chim. Acta, 44, 412 ('61); 166) L. P. Kholpanov, S. V. Gorbachev: Zhur. Fiz. Khim., 36, 855 ('62); 167) V. A. Belyaeva: ibid., 36, 1385 ('62); 168) Z. Galus, C. Olson, H. Y. Lee, R. H. Adams: Anal. Chem., 34, 164 ('62); 169) G. P. Desideryev, S. I. Brrezina: Doklady Akad. Nauk. SSSR, 130, 1270 ('61); 170) R. Landsberg, W. Geissler, S. Müller: Z. Chem., 1, 169 ('61).

171) Z. Zembura: Bull. acad. polon. sci. Sér. sci. chim., 9, 531 ('61); 172) N. Tanaka: Progress, 523 ('62); 173) L. Meites: ibid., 515 ('62); 174) L. Serak: ibid., 535 ('62); 175) J. V. A. Novak: ibid., 569 ('62); 176) T. Fujinaga, S. Oka: Rev. Polarography, 9, 243 ('61); 177) E. D. Kokhman: Zhur. Fiz. Khim., 35, 214 ('61); 178) S. Wolf: Z. anal. Chem., 186, 87 ('62); 179) K. Kronenberger, W. Nickels: ibid., 186, 79 ('62); 180) P. O. Kane: J. Polarographic Soc., 8, 10 ('62).

181) J. E. Seaborn: A. E. R. E. Report, R 3630 ('61); 
182) H. I. Shalgosky, J. Watling: Anal. Chem., 26, 66 ('62); 183) G. C. Barker, A. W. Gardner: A. E. R. E. Report, C/R, 2297 ('61); 184) L. Jansovsky: Chem. Tech., Berlin, 13, 519 ('61); 185) J. H. Hayes, G. H. Aylward: Anal. Chem., 34, 1039('62); 186) C. Auerbach, H. L. Finston, G. Kissel, J. Glickstein: ibid., 33, 1480 ('61); 187) Ya. I. Tur'yan: Zavod. Lab., 28, 98 ('62); 188) W. J. Parker: Metal Ind., 100, 82, 105 ('62); 189) Anonymous: Lab. Practice, 10, 537 ('61); 190) R. Kalvoda, I. Smoler: Zavod. Lab., 27, 549 ('61).

191) M. Becker: Angew. Chem., 73, 495 ('61) 192) P. Arthur, P. A. Lewis, N. A. Lloyd, R. K. Vanderkam: Anal. Chem., 33, 488 ('61); 193) P. Arthur, R. K. Vanderkam: ibid., 33, 765 ('61); 194) H. B. Mark, C. N. Reilley: J. Electroanal. Chem., 3, 54 ('62); 195) A. Hickling: Electrochim. Acta, 5, 161 ('61); 196) C. H. Holten: Acta Chem. Scand., 15, 956 ('61); 197) J. M. Matsen, H. B. Linford: Anal. Chem., 34, 142 ('62); 198) A. L. Beilby, A. L. Budd: ibid., 34, 493 ('62); 199) C. K. Mann, V.C. Champeaux: J. Chem. Educ., 38, 519('61); 200) R. Barnard, R. Woodriff: ibid., 38, 527 ('61).

201) G. W. Walkiden: Chem. \& Ind., 40, 1614 ('61); 202) C. K. Mann: Anal. Chem., 33, 1484 ('61); 203) R. Briggs, W. H. Mason: Lab. Practice, 11, 36 ('62); 204) J. L. Founders: ibid., 11, 209 ('62); 205) J. Peizker: Collection, 26, 230 ('61); 206) 玉虫伶太: ポーラログラフィ -, 10, 1 ('62); 207) J. Koutecky, M. von Stackelberg: Progress, 21 ('62); 208) J. Kuta, I. Smoler: ibid., 43 ('62); 209) J. E. B. Randles: ibid., 123 ('62); 210) R. Brdicka, H. Hanus, J. Koutecky: ibid., 145 ('62).

211) W. Lorenz. G. Salié: Z. physik. Chem. (Frankfurt), 29, 390 ('61); 212) L. Meites, Y. Israel: J. Am. Chem. Soc., 83, 4903 ('61); 213) A. Regner, D. Balej: Collection, 26, 296 ('61); 214) J. Kuta, I. Smoler: ibid., 26, 224 ('61); 215) M. Breant, J. C. Merlin: Bull. soc. chim. France, 2295 ('61); 216) I. Shain, D. S. Polcyn: J. Phys. Chem., 65, 1649 ('61); 217) H. Tribel, H. Berg: J. Electroanal. Chem., 2, 467 ('61); 218) Z. Zembura, A. Fulinski, B. Bierowski: Z. Elektrochem., 65, 887('61); 219) D. G. Peters, J. J. Lingane: J. Electroanal. Chem., 2, 249 ('61); 220) W. H. Reinmuth: Anal. Chem., 33, 1793 ('61).

221) W. H. Reinmuth: ibid., 33, 185 ('61); 222) I. Shain, J. Lewinson: ibid., 33, 187 ('61); 223) L. P. Kholpanov: Zhur. Fiz. Khim., 36, 214 ('62); 224) L. P. Kholpanov: ibid., 35, 2223 ('61); 225) 高木正之助: ポーラ ログラフィー, 9, 53 ('61); 226) R. Takahashi, I. Tachi: Rev. Polarography, 9, 76 ('61); 227) G. A. Rechnitz, H. A. Laitinen: Anal. Chem., 33, 1473 ('61); 228) P. Delahay, M. Senda, C. H. Weis: J. Am. Chem. Soc., 83, 312 ('61); 229) J. Paynter, W. H. Reinmuth: Anal. Chem., 34, 1335 ('62); 230) B. Breyer, J. R. Beevers, H. H. Bauer: J. Electroanal. Chem., 2, 60 (' 61 ).

231) G. Salié, W. Lorenz: Z. physik. Chem. (Frankfurt), 29, 408 ('61); 232) N. G. Lordi: Anal. Chem., 34, 1832 ('62); 233) F. I. Kukoz, L. A. Kukoz: Zhur. Fiz. Khim., 36, 703 ('62); 234) 守永健一: ポーラログラフィー,9,97 ('61); 235) A. N. Frumkin, N. Nikolaeva-Fedorovich: Progress, 223 ('62); 236) P. Delahay: ibid., 65 ('62); 237) C. N. Reilley, W. Stumm: ibid., 81 ('62); 238) B. B. Damaskin: Uspekhi Khim., 30, 220 ('61); 239) D. C. Grahame, R. Parsons: J. Am. Chem. Soc., 83, 1291 ('61); 240) M. J. Austin, R. Parsons: Proc. Chem. Soc., 239 ( 61 ).

241) P. J. Elving, D.L. Smith: Nuclear Sci. Abstr., 15, 2499 ('61) No. 19209; 242) A. Ya. Gokhstein: Doklady Akad. Nauk, SSSR, 137, 345 ('61); 243) V. I. Zykov: Zhur. Fiz. Khim., 35, 355 ('61); 244) O. L. Kabanova:
Zhur. Anal. Khim., 16, 135 ('61); 245) J. J. Tondeur, A. Dombret, L. Gierst: J. Electroanal. Chem., 3, 225 ('62); 246) J. Koryta: Chem. Listy, 55, 63 ('61); 247) O. Dracka: Collection, 26, 1999 ('61); 248) F. Peter, I. Szabados, G. Palyi: Acta Chim. Acad. Sci. Hung., 27, 163 ('61); 249) L. Holleck, H. Tuphorn: Naturwiss. 48, 71 ('61); 250) R. A. Munson: J. Phys. Chem., 66, 727 ('62).

251) W. M. MacNevin, S. R. Steele: Anal. Chim. Acta, 24, 381 ('61); 252) I. M. Kolthoff, J. C. Marshall, S. L. Gupta: J. Electroanal. Chem., 3, 209 ('62); 253) F. Willeboordse: ibid., 2, 408 ('61); 254) I. Rusznak, L. Kralik, K. Fukker: Collection, 26, 645 ('61); 255) I. Rusznak, I. Kralik, K. Fukker: ibid., 26, 1262('61); 256) R.J. Bearman: J. Phys. Chem., 66, 2072('62); 257) GaoTsai-Shen, Ya. P. Gokhstein: Zhur. Fiz. Khim., 35, 404 ('61); 258) S. N. Mukherjee, A. M. Gosh, A. Chakravarti: J. Sci. Ind. Research (India), 20B, 77 ('61); 259) I. M. Kolthoff, Y. Okinaka: J. Am. Chem. Soc., 83, 47 ('61); 260) A. H. M. Cosijn: J. Electroanal. Chem., 2, 437 ('61).

261) E. Pungor, G. Farsang: Magyar Kem. Folyorat, 67, 293 ('61); 262) O. S. Ksenzhek: Zhur. Fiz. Khim., 36, 243, 633 ('62); 263) V. F. Ivanov, Z. A. Yofa: Doklady Akad. Nauk, SSSR, 137, 1149 ('61); 264) R. A. Osteryoung, G. Lauer: Anal. Chem., 34, 1833 ('62); 265) M. Heyrovsky: Collection, 26, 3164 ('61); 266) G.F. Reynolds: Progress, 243 ('62); 267) A. A. Vlcek: ibid., 269 ('62); 268) J. Koryta: ibid., 291 ('62); 269) G. W. C. Milner: ibid., 601 ('62); 270) M. Shinagawa: ibid., 617 ('62).

271) J. Zyka: ibid., 649 ('62); 272) 真木伸文: ポーラロ グラフィー, 9, 203 ('61); 273) A. Tockstein: Z. Chem., 1, 3, 34 ('61)；274） 北川豊吉：ポーラログラフィー, 9, 87 ('61); 275) G.S. Supin: Zhur. Anal. Khim., 16, 359 ('61); 276) 松岡学: 日化, 82, 1036('61); 277) N. Tanaka, M. Kamada, G. Sato: Bull. Chem. Soc. Japan, 34, 541 ('61); 278) N. Tanaka, H. Ogino: ibid., 34, 1040 ('61); 279) R. L. Pecsok, R. L. Meeker, L. D. Shields: J. Am. Chem. Soc., 83, 2081 ('61); 280) C. J. Nyman, D. K. Roe, R. A. Plane: ibid., 83, 323 ('61).

281) L. Newman, D. N. Hume: ibid., 83, 1795 ('61); 282) D. K. Roe, D. B. Masson, C. J. Nyman: Anal. Chem., 33, 1464 ('61); 283) C. J. Nyman, T. Salazar: ibid., 33, 1467 ('61); 284) J. Vodehnal: Collection, 26, 21 ('61); 285) H. W. Nürnberg, G. van Riesenbeck, M. von Stackelberg: ibid., 26, 126 ('61); 286) K. B Yatsimirski, L. I. Budarin: ibid., 26, 215 ('61); 286a) D. L. McMasters, J. C. Di Raimondo, L. H. Jones, R. P Lindley, E. W. Zeltmann: J. Phys. Chem., 66, 249 ('62); 287) H. A. McKenzie, D.P. Mellor: Australian J. Chem., 14, 562 ('61); 288) A. R. Selmer-Olsen: Acta Chem. Scand., 15, 2052 ('61); 289) W. Kemula, A. Hulanicki: Bull. acad. polon. sci., śer. sci. chim., 9, 477 ('61); 290) P. N. Kovalenko: Zhur. Neorg. Khim., 6, 539 ('61).

291) I. Miklos, R. Szegedi: Acta Chim. Acad. Sci. Hung., 26, 365 ('61); 292) H. Hahn, R. Wagenknecht: Z. anal. Chem., 182, 343 ('61); 293) 志村博; 日化, 82, 641 ('61); 294) E. Jacobsen, K. Schröder: J. Phys. Chem., 66, 134('62); 295) A.V. Pamphilov, A.O. Lopushanskaya, T. S. Isther: Ukrai. Khim. Zhur., 27, 598 ('61); 296) P. R. Subraman, P. S. Shetty, J. Gupta: Anal. Chim. Acta, 26, 179 ('62); 297) W. B. Schaap, D. L. McMasters: J. Am. Chem. Soc., 83, 4699 ('61); 298) G. S. Deshmukh: J. Sci. Ind. Research (India), 21B, 144 ('62); 299) J. Dolezal, J. Zyka: Zhur. Anal. Khim., 16, 395 ('61); 300) V. F. Toropova, G. L. Vel'kes: ibid., 17, 282 ('62).

301) J. Dolezal, V. Petrus, J. Zyka: J. Electroanal. 
Chem., 3, 274 ('62); 302) A. G. Stromberg, M. S. Zakharov, V. E. Gorodovikh, L. F. Zatshiko: Zavod. Lab., 27, 517 ('61); 303) S. I. Sinyakova, I. V. Markova: ibid., 27, 521 ('61); 304) T. Kitagawa, K. Nakano: Rev. Polarography, 9, 121 ('61); 305) 斎藤篤 義：日化， 82，214，715，718 ('61); 306） R. M. Dognall, T. S. West: Talanta, 9, 925 ('62); 307) I. A. Kedrinsky: Zavod. Lab., 27, 538 ('61); 308) J. Badoz-Lambling, M. Sato: Compt. rend., 254, 3354 ('62); 309) T. M. Florence: Anal. Chem., 34, 496 ('62); 310) E. A. Terent'eva: Zavod. Lab., 28, 807 ('62).

311) L. Vignoli, B. Cristau, F. Gouezo: Chim. Anal., 44, 3 ('62); 312) L. Vignoli, B. Cristau, F. Gouezo: ibid., 43, 439 ('61); 313) G. F. Reynolds, E. A. Terry: J. Polarog. Soc., 7, 2 ('61); 314) F. Rab: Chem. Listy, 55, $919\left({ }^{\prime} 61\right)$ ； 315） 永田美之介, 北尾弘一郎, 舘勇: 電化, 29, 298 ('61); 316) S. P. Shaikind, N. M. Koitsinskaya: 'Trudy Leningr. Technol. Inst. im Lensoveta, 55, 173 ('61); 317) P. Senise, E. F. de Almeida: J. Am. Chem. Soc., 83, 4146 ('61); 318) M. Kodama: Bull. Chem. Soc. Japan, 34, 714 ('61); 319) V. A. Oshman, A. P. Tshistyakova: Zavod. Lab., 27, 532 ('61); 320) M. Shinagawa, H. Nezu, T. Yamada: Rev. Polarography, 10, $126\left({ }^{\prime} 62\right)$.

321) H. Sunahara: ibid., 9, 158, $165\left({ }^{\prime} 61\right)$; 322) H. Nezu: ibid., 10, 154 ('62); 323) N. Maki, R. Tsuchida: Bull. Chem. Soc. Japan, 34, 891 ('61); 324）柳忠, 黒田甲 子郎: 日化, 82, 1641, 1644 ('61); 325) E. B. Weronski: J. Phys. Chem., 65, 564 ('61); 326) E. B. Weronski: ibid., 65, 2110 ('61); 327) P. Silvestroni, L. Ceciarelli: J. Am. Chem. Soc., 83, 3905 ('61); 328) W. Haerdi, J. Vogel, D. Monnier: Acta Chem. Acad. Sci. Hung., 26, 105 ('61); 329) S. P. Shaikind, E. F. Makarova: Trudy Leningr. Tekhnol. Inst. im Lensoveta, 55, 173 ('61); 330) W. W. Ullman, B. H. Pfeil, J. D. Porter, W. W. Sanderson: Anal. Chem., 34, 213 ('62).

331) E. Budevskii, S. Toshev: Doklady Akad. Nauk, SSSR, 130, 1047 ('61); 332) Z. A. Soloveva, A. T. Vagramyan: Zhur. Fiz. Khim., 36, 752 ('62); 333) W. Kemula, E. Rakowska: Roszniki Chem., 36, 203 ('62); 334) E. Fischerova, O. Fischer: Collection, 26, 2570('61); 335) M. A. Levine, T. P. Jones, W. E. Harris, W. J. Wallace: J. Am. Chem. Soc., 83, 2453 ('61); 336) G. H. Aylward, J. L. Garnett, J. W. Hayes, S. W. Law: J. Inorg. Nuclear Chem., 16, 350 ('61); 337) 白井ひで子; 日 化, 82, 1179 ('61); 338) J. Gazo, J. Süss: Chem. Zvesti, 15, 113 ('61); 339) W. U. Malik, A. A. Khan, R. Haque: Naturwiss., 48, 47 ('61); 340) J. F. Fisher, J. L. Hall: Anal. Chem., 34, 1094 ('62).

341) P. G. Desideri: J. Electroanal. Chem., 2, 39 ('61); 342) R. C. Rooney, P. J. McIver: Analyst, 87, 895 ('62); 343) O. A. Petrii, N. V. Nikolaeva-Fedorovich: Zhur. Fiz. Khim., 35, 1999 ('61); 344) M. Kopanica, R. Pribil: Collection, 27, 17 ('62); 345) N. Konopik: $Z$. anal. Chem., 186, 127 ('62); 346) N. V. Stashkova, A. I. Zelyanskaya: Izvest. Sibir. Otdel. Akad. Nauk SSSR, 72 ('61); 347) D. K. Roe, D. B. Masson, C. J. Nyman: Anal. Chem., 33, 1464 ('61); 348) C. J. Nyman, T. Salazar: ibid., 33, 1467 ('61); 349) Kh. Z. Braygina: Doklady Akad. Nauk, SSSR, 130, 797 ('61); 350) E. N. Vinogradova, A. Tsin-Zhu: Zhur. Ana1. Khim., 16, 555 ('61).

351) E. D. Moorhead, W. M. MacNevin: Anal. Chem., 34, 269 ('62); 352) P. G. Pats, S. B. Tafasman: Zavod. Lab., 27, 266 ('61); 353) S. L. Phillips, E. Morgan: Anal. Chem., 33, 1192 ('61); 354) M. Kvacek, P. Kühn: Chem. Listy, 55, 1296 ('61); 355) J. A. Page: Talanta, 9, 365 ('62); 356) Ya. I. Tur'yan, V.F. Romanov:
Khim. Prom., 68 ('61); 357) T. M. Florence, L. E. Smythe: Nuclear Sci. Abstr., 15, 2494 ('61); 358) R. Landsberg, J. Hendel, W. Müller: J. Electroanal. Chem., 2, 484 ('61); 359) S. V. Gorbachev, V. A. Belyaeva: Zhur. Fiz. Khim., 36, 229 ('62); 360) R. Landsberg, W. Müller, J. Hendel: J. Electroanal. Chem., 2, $400\left(^{\prime} 61\right)$. 361) I. Adam, J. Dolezal, J. Zyka: Zhur. Anal. Khim., 16, 592 ('61); 362) W. Jakob, M. Ogorzatek, H. Sikorski: Roczniki Chem., 35, 3 ('61); 363) W. Jacob, J. Chojnacka: ibid., 35,13('61); 364) G.Piccardi, F.Pantani: Ricerca Sci., (2A) 31, 187 ('61); 365) F. Pantani: ibid., 31, $12\left({ }^{\prime} 61\right)$; 366) G. P. Haight Jr.: Acta Chem. Scand., 15, 2012 ('61); 367) E. W. Zahnow, R. J. Robinson: J. Electroanal. Chem., 3, 263 ('62); 368) K. Grasshoff, H. Hahn: Z. anal. Chem., 187, 18, 147, 328 ('62); 369) P. H. Ke Buncak: Chem. Prumysl., 11, 634 ('61); 370) S. Spauszus, J. Hupfer: Chem. Tech., Berlin, 13, 750 ('61).

371) J. H. Kennedy: Anal. Chem., 33, 943 ('61); 372) J. Dandoy, L. Gierst: J. Electroanal. Chem., 2, 116 ('61); 373) V. S. Griffiths, J. B. Westmore: J. Chem. Soc., 1704 ('62); 374) I. Adam, J. Dolezal, J. Zyka: Zhur. Anal. Khim., 16, 395 ('61); 375) 白井ひで子: 日化, 82, 339 ('61); 376) D. Weiss: Z. anal. Chem., 185, 273 ('62); 377) R. E. Cover, L. Meites: J. Am. Chem. Soc., 83, 4706 ('61); 378) V. Vojir: Collection, 26, 289 ('61); 379) TsaiTeh, Teh-Liang Chang: Anal. Chem., 33, 1953 ('61); 380) H. Specker, H. Trüb: Z. anal. Chem., 186, 123 ('62). 381) R. Carson: Analyst, 86, 198 ('61); 382) A. P. Mead, A. Parker, E. A. Terry: A. E. R. E. Report, 3763 ('61); 383) R. Ralea, O. Vicol-Ungureanu: An. Stut. Univ. “Al. I. Cuza” Iasi, Sect. 1, 6, 387 ('60); 384) N. V. Nikolaeva-Fedorovich, O. A. Petrii: Zhur. Fiz. Khim., 35, 1270 ('61); 385) K. Györbiro: Acta Chim. Acad. Sci. Hung., 27, 119 ('61); 386) D. M. Wagnerova: Collection, 26, 2076 ('61); 387) D. Cozzi, F. Pantani: J. Electroanal. Chem., 2, 72 ('61); 388) D. Cozzi, F. Pantani: ibid., 2, 230 ('61); 389) N. K. Pshenitsin, N. A. Ezerskaya: Zhur. Anal. Khim., 16, 196 ('61); 390) D. M. Wagnerova: Collection, 27, 1130 ('62).

391) R. E. Humphrey: Anal. Chem., 34, 167('62); 392) T. Lewandowska, Z. Gwiazda: Chemia anal., 8, 29 ('61); 393）吉野隆：日化, 82, 1012 ('61); 394) L. Treindl: Collection, 26, 3003 ('61); 395) B. Nygard: Acta Chem. Scand., 15, 1039 ('61); 396) C. LePeintre: Compt. rend., 253, 1696 ('61); 397) Z. Habermann: Sklar a Keram, 12, 9 ('62); 398) R. Bock, H. Kau: Z. anal. Chem., 188, 28 ('62); 399) G. S. Deshmukh, O. P. Asthana: Naturwiss., 48, 477 ('61); 400) V. V. Malakhov: Zavod. Lab., 28, 408 ('62).

401) A. J. Bard: Anal. Chem., 34, 266 ('62); 402) 宮 本益夫: 分化, 10, 438 ('61); 403) M. Ariel, E. Kirowa: Talanta, 8, 214 ('61); 404) G. S. Deshmukh, Y. D. Kane: J. Sci. Ind. Research India, B21, 235 ('62); 405) S. L. Phillips, I. Shain: Anal. Chem., 34, 262 ('62); 406) R. D. DeMars: ibid., 34, 259 ('62); 407) J. Cantacuzene, R. Zermizoglou: Bull. soc. chim. France, 283 ('62); 408) 平田寛, 雨宮稳起: 日化, 82, $1285\left({ }^{\prime} 61\right)$ ； 409) 北川豊吉: 分化, 10, 603 ('61); 410) R. E. Kirby, H. Freiser: J. Phys. Chem., 65, 191 ('61).

411) S. F. Shaikind, I. A. Alekhina, L. T. Danilov: Trudy Leningr. Tekhnol. Inst. im Lensoveta, 55, 173 ('61)； 412） 児玉睦夫: 日化, 82, 1208 ('61); 413) I. M. Kolthoff, S. Ikeda: J. Phys. Chem., 65, 1020 ('61); 414) A. G. Stromberg, A. I. Kartushinskaya: Zhur. Fiz. Khim., 35, 1058 ('61); 415) R. Takahashi: Rev. Polarography, 9, 116 ('61); 416) R. Tamamushi, N. Tanaka: Z. physik. Chem. (Frankfurt), 28, 158 ('61); 417) P. S. Shetty, P. R. Subbraman, J. Gupta: Anal. 
Chim. Acta, 27, 429 ('62)

418）藤永太一郎，伊豆津公祐： 分化, 10, 63 ('61) 419) A. G. Stromberg, A. I. Kartushinskaya: Izvest. Sibir. Otdel Nauk, SSSR, 11, 88 ('61); 420) J. Hala, A. Okac: Collection, 27, 1697 ('62).

421) H. E. Zittel, L. B. Dunlop: Anal. Chem., 34, 1757 ('62); 422) D. G. Davis: ibid., 33, 492 ('61); 423) Tsai-Teh Lai, Teh-Liang Chang: ibid., 33, 1193 ('61); 424) W. V. Childs, E. S. Amis: J. Phys. Chem., 65, 1080 ('61); 425) R. C. Propst: Nuclear Sci. Abstr., 15, 3355 ('61); 426) E. Palfi, B. Hadobas: Acta Chim. Acad. Sci. Hung., 27, 155 ('61); 427) J. Minczewski, A. Sobkowska: ibid., 27, 143 ('61); 428) J. P. Gokhstein, Gao Caj-shen: Zhur. Neorg. Khim., 6, 157 ('61); 429) S. P. Shaikind, S. V. Solov'eva, S. A. Smiryagina: Trudy Leningr. Tekhnol. Inst. im Lensoveta, 55, 172 ('61); 430) W. V. Childs, E. S. Amis: J. Polarog. Soc., 7, 30 ('61).

431) V. G. Sochevanov, N. V. Shmakova, L. T. Martynova, G. A. Volkova: Zhur. Anal. Khim., 16, 362 ('61); 432) G. S. Deshmukh, J. P. Srivastava: Bull. Chem. Soc. Japan, 34, 325 ('61); 433) Y. Yasumori, T. Eguchi, M. Nishiyama: Rev. Polarography, 9, 62 ('61); 434) R. Ripan, A. Duca, M. Puscasu, D. Stanescu: Bull. soc. chim. France, 765 ('61); 435) F. Pantani, P. Desideri: Ric. Sci. (2A) 31, 249 ('61); 436) M. Kodama, M. Hashimoto: Bull. Chem. Soc. Japan, 35, 1802 ('62); 437) R. Landsberg, V. Stockmann, W. Geissler: Z. physik. Chem. (Leipzig), 217, 368 ('61); 438) D. T. Sawyer, R. J. Kula: J. Electroanal. Chem., 3, 407 ('62); 439) Tshang-Ye-Sia, J. Dolezal, J. Zyka: Collection, 26, 1768 ('61); 440) R. Carson: Analyst, 86, 198 ('61).

441) K.Zh. Sagadieva:Vestnik Akad. Nauk, Kazak. SSR, (1), 17, 77 ('61); 442) E. M. Roizenblat, Kh. Z. Brainina: Zavod. Lab., 27, 1197 ('61); 443) W. Czarnecki, M. Perec, A. Weglarczyk: Roczniki Chem., 36, 503 ('62); 444) I. N. Sheiko, A. V. Gorodyskii, V. V. Kuzmovitsh: Ukrain. Khim. Zhur., 27, 767 ('61); 445) D. T. Sawyer, L. V. Interrante: J. Electroanal. Chem., 2, 310 ('61); 446) R. Cornelissen, L. Gierst: ibid., 3, 219 ('62); 447) V. S. Griffiths, M. I. Jackman: Talanta, 9, 205, 871 ('62); 448) E. A. Rice: Rev. Sci. Instr., 32, 892 ('61); 449) I. S. Longmuir, F. Allen: J. Polarogr. Soc., 7, 63 ('61); 450) J. D. Eye, L. H. Reuter, K. Keshavan: Water and Sewage Works, 108, 231 ('61).

451) W. Heimann, K. Wisser: Z. anal. Chem., 185, 266 ('62); 452) A. H. Meyling, G. H. Frank: Analyst, 87, 684 ('62); 453) A. Rius, A. Sacristan: Electrochim. Acta, 6, 155 ('62); 454) 岩瀬秋雄: 日化, 82, 264 ('61); 455) Kh. Z. Braynina, E. M. Rosenblat: Zavod. Lab., 28, 21 ('62); 456) V. P. Gladyshev, R. Kalvoda: ibid., 27, 1450 ('61); 457) V. Priska: Z. anal. Chem., 184, 17 ('61); 458) W. Geissler, R. Landsberg: Z. Chem., 1, 308 ('61); 459) A. Berka, J. Dolezal: Anal. Chim. Acta, 24, 476 ('61); 460) J. Hetman: Lab. Practice, 10, 155 ('61).

461) E. Michalski, A. Wtorkowska: Chem. anal. Warsaw, 6, 365 ('61); 462) M. Spalenko: Progress, 661 ('62); 463) D. Cozzi: ibid., 703 ('62); 464) I. Tachi, M. Senda: ibid., 711 ('62); 465) E. N. Vinogradova, L. N. Vasileva, K. Yobst: Zavod. Lab., 27, 525 ('61); 466) D. S. Turnham: J. Polarog. Soc., 7, 43 ('61); 467) G. Farsang, E. Pungor: Acta Chim. Acad. Sci. Hung., 27, $113\left({ }^{\prime} 61\right)$; 468) D. S. Turnham: J. Electroanal. Chem., 2, 388 ('61); 469) 田島信雄, 黒部森 司: 分化, 10, 146 ('61); 470) F. A. Poh1, W. Bonsels: Mikrochim. Acta, 314 ('61).

471) T. M. Florence, D. B. Izard: Anal. Chim. Acta, 25, 386 ('61); 472) E. K. Prokofyev: Zavod. Lab., 27,
530 ('61); 473) S. N. Mladenovic: Glasnik Khem. Drushtva, Beograd, 23/24, 529 ('59/60); 474) S. N. Mladenovic: ibid., 23/24, 535 ('59/60); 475) S. I. Sinyakova, N. A. Rudnev, Shen-Yu-Chi, R. Jumaev: Zhur. Anal. Khim., 16, 32 ('61); 476) Ya. P. Gokhstein, M. P. Volynets, V. D. Yukhtanova: Trudy Komiss. Anal. Khim., Akad. Nauk, SSSR, 12, $5\left({ }^{\prime} 60\right)$; 477) P. H. Scholes: Analyst, 86, $392\left({ }^{\prime} 61\right)$; 478) P. H. Scholes: R. \& D., 5, 38 ('62); 479) A. G. C. Morris: Analyst, 87, 478 ('62); 480) P. H. Scholes: ibid., 86, 116 ('61).

481) S. Maekawa, Y. Yoneyama: J. Japan Inst. Metals, Sendai, 25, 651 ('61); 482) R. C. Rooney: J. Polarog. Soc., 10, 446 ('62); 483) K. R. J. Cottell: Nuclear Sci. Abstr., 15, 2491 ('61); 484) 浅岡博: 分化, 10, 255 ('61); 485) W. Kemula, S. Rubel: Acta Chim. Acad.Sci. Hung., 27, 133 ('61); 486) W. Kemula, S. Rubel: Chem. anal., Warsaw , 6, 347 ('61); 487) W. Kemula, K. Brajter, S. Rubel: ibid., 6, 331 ('61); 488) M. Kopanica, R. Pribil: Collection, 26, 398 ('61); 489) 伊賀武, 山下正平, 上原博義：分化, 10, 227 ('61); 490) 立木正共: 雪化, 29, 42 ('61).

491) V. T. Athavale, R. G. Dhaneshwann, M. M. Nehta, M. S. P. Antal: Analyst, 86, 399 ('61); 492) D. I. Kurbatov: Zhur. Anal. Khim., 16, 36 ('61); 493) V. T. Athavale, R. G. Dhaneshwann, S. V. Gulavane, M. S. Varde: Anal. Chem., 33, 311 ('61); 494) R. G. Pats, T. V. Semochkina: Zavod. Lab., 28, 800 ('62); 495) 斎 藤謙, 武内次夫：分化, 10, 152 ('61); 496) J. Provaznik, J. Mojzis: Chem. Listy, 55, 1299 ('61); 497) D. P. Stricos: Nuclear Sci. Abstr., 15, 2496 ('61); 498) D. F. Wood, R. T. Clark: Analyst, 87, 342 ('62); 499) E. Görlich, Z. Kowalski, H. Przewlocka: Chem. anal., Warsaw, 6, 675 ('61); 500) E. Görlich, H. Przewlocka: ibid., 6, 685 ('61).

501) D. Ya. Ryabtshikov, Ya. P. Gokhstein, GaoTsai-Shen: Zhur. Anal. Khim., 16, 709 ('61); 502) E. Görlich, Z. Kowalski: Chem. anal., Warsaw, 6, 937('61); 503) V. V. Zhirova: Geokhimiya, 6, $542\left({ }^{\prime} 62\right)$; 504) P. G. Pats: Zavod. Lab., 28, 18 ('62); 505) L. N. Lyuibimova, V. G. Sotshevanov: ibid., 28, 15 ('62); 506) I. Carmichael, A. McDonald: Geochim. Cosmochim. Acta, 22, 87 ('61); 507) D. Weiss: Rudy (Prague), 9, 15 ('61); 508) V. B. Spivakovski, V. A. Zimina, L. S. Gavrilyuk: Zavod. Lab., 27, 390 ('61); 509) L. Jarman, M. Matic: Talanta, 9, 219 ('62); 510) C. H. Holten: Acta Chem. Scand., 15, 943 ('61).

511) Yu. B. Moratshevski, A. I. Kalinin: Zavod. Lab., 27, 272 ('61); 512) R. E. Stanton, A. J. McDonald, I. Carmichael: Analyst, 87, 134 ('62); 513) L. Vignoli, B. Cristau, F. Gouezo: Ann. Fals. et fraudes, 54, 132 ('61); 514) J. C. Sirois: Analyst, 87, 900 ('62); 515) E. Przybylski: Chem. anal., Warsaw, 6, 749 ('61); 516) D. N. Ostrovskii, N. S. Gel'man: Biokhimiya, 27, 532 ('62); 517) Z. Brzezinska, E. Szyszko: Roczn. Zakt. Hig., Warsaw, 13, 215 ('62); 518) L. Jensovsky, Z. Roth: Naturwiss., 48, 382 ('61); 519) J. Vogel, D. Monnier: Mitt. Lebensmitt. Hyg., Bern, 52, 539 ('61); 520) A. G. Faulkner, E. C. Knobloch, W. C. Purdy: Clin. Chem., 7, 22 ('61).

521) P. S. Bukharov, V. K. Fertman, V. G. Koshkina: Vinodelie i Vinogradarstvo SSSR, 7, 32 ('61); 522) W. F. Condliffe, A. J. H. Skrimshire: J. Polarog. Soc., 7, 10 ('61); 523) 瀬戸寿太郎: 分化, 10, 401 ('61); 524) E. C. Knobloch, W. C. Purdy: J. Electroanal. Chem., 2, 493 ('61); 525) Z. Ferenczy: Acta Chim. Acad. Sci. Hung., 26, 229 ('61); 526) 石井猛：ポーラログラフィー, 10, 62 ('62); 527) T. Ishii, T. Kambara: Rev. Polarography, 10, 72 ('62); 528) G. R. Schultze, W. Irion: Angew. 
Chem., 73, 147 ('61); 529) G. R. Schultze, W. Irion: Z. anal. Chem., 181, 200 ('61); 530) B. W. Samuel, J. V. Brunnocks: Anal. Chem., 33, 203 ('61).

531) L. Miczko: Ceskoslov. farm., 10, 289 ('61); 532) M. S. Bishovskaya, I. A. Orlova: Zavod. Lab., 27, 540 ('61); 533) Z. Kublik: Acta Chim. Acad. Sci. Hung., 27, 79 ('61); 534) G. W. C. Milner, J. D. Wilson, G. A. Barnett, A. A. Smales: J. Electroanal. Chem., 2, 25('61); 535) P. Antal: Microchim. Acta, 2, 235 ('61); 536) G. C. Whitnack: J. Electroanal. Chem., 2, 110 ('61); 537) V. Cielenzky, L. Sebessy: Pharmazie, 16, 65 ('61); 538) E. Kh. Rud, S. Ya. Skatshilova, K. B. Kopylova: Zavod. Lab., 27, 1454 ('61); 539) A. Tockstein, V. Novak: Microchim. Acta, 142 ('62); 540) S. L. Phillips, E. Morgan: Anal. Chem., 33, 1192 ('61).

541) L. Vignoli, B. Cristau, F. Gouezo: Chim. Anal., 43, 439 ('61); 542) R. Geyer, M. Geissler: Z. anal. Chem., 187, 251 ('62); 543) J. Trnka: Collection, 25.
2232 ('61); 544) J. Gallus-Olender: Chemia anal., 6, 269 ('61); 545) J. Branzovsky, O. Kusak: Chem. prumysl., 11, 134 ('61); 546) K. J. Cathro: Analyst, 86, 657 ('61); 547) A. H. Craft, K. Schumpelt: Plating, 48, 277 ('61); 548) J. A. Miller: ibid., 48, 1110 ('61); 549) E. M. Skobets, I. L. Abarbarchuk, K. P. Kostitsina: Nauk, Pratsi. Ukr. Akad. Sil's'kogospod. Nauk, 11, 125 ('60); 550) V. J. Jennings: Analyst, 87, 548 ('62).

551) T. M. Florence: Anal. Chem., 34, 496 ('62); 552) R. Annino, J. E. McDonald: ibid., 33, 475 ('61); 553) J. Armand, P. Souchay: Chim. Anal., 44, 239 ('62); 554) G. W. Skyring, B. J. Carey, V. B. D. Skerman: Soil Sci., 91, 388 ('61); 555) B. Enyedi, Gy. Bencz, F. Bagyinszki: Magyar Kem. Lapja, 16, 131 ('61); 556) L. Vignoli, B. Cristau, F. Gouezo: Chim. anal., 44, 3 ('62); 557) W. Kemula, Sz. Rozolowski: Roczniki Chem., 36, 179 ('62). 